\title{
THE DANUBE RIVER AS AN ACTIVATION FACTOR OF THE ETHNOPEDAGOGICAL COMPONENT OF GENERAL CULTURAL COMPETENCE OF BACHELORS IN NATURAL SCIENCES
}

\author{
Nadiia Gramatyk \\ Department of General Pedagogy, Pre-school, Primary and Special Education \\ Izmail State Humanitarian University \\ 12 Repina str., Izmail, Ukraine, 68610 \\ E-mail: Gramatiknadea@gmail.com
}

\begin{abstract}
In accordance with the European parameters of professional training of the new formation of educators, it is mandatory to emphasize the problem of forming in the future teacher the basic competencies of modern human, including an ethnocultural one. The value of this format of professional training is the focus of competence-oriented content of education on the formation of life and worldview of the future teacher, as well as his/her professional self-development. Ethnopedagogical component of training of future bachelors of natural sciences is of particular importance in the implementation of the concept of specialized training in high school and is one of the indicators of professional readiness to implement the multicomponent component of the content of modern natural education. Ethnopedagogy as a component of modern pedagogical science is a powerful resource for the formation of general cultural competence of the future teacher, which reflects a certain level of his/her professional readiness for teaching in the context of interaction of natural and social environments, to emphasize semantic and ideological aspects, to highlight the dominance of new values.

Keywords: ethnopedagogy, general cultural competence, ethnopedagogical preparation of future bachelors of natural sciences, ethnocultural experience, multicultural educational space.
\end{abstract}

DOI: $10.21303 / 2504-5571.2021 .001759$

\section{Introduction}

An essential feature of modern education is the cultural dominant, as part of the general cultural competence of the individual. The need to train a competent specialist capable of effective pedagogical activity in a multinational environment is a priority area of professional training of future science teachers in the parameters of European standards. Since general cultural competence as a component of professional competence of future bachelors of natural sciences is laid in student age, so practical-oriented training should be aimed at implementing the ethnocultural component of educational content and at providing ethnopedagogical experience as a basis for integrating personality into the system of social professions. In addition, the ethnopedagogical aspect of modern subject training of future bachelors of natural sciences acts not only as a process of purposeful influence on the individual, but also as the space of interpersonal relationships, which form a holistic culture of personality and professional identity. It should be added, that the problem of the regional peculiarity of intercultural interaction is today in the center of attention of the broad pedagogical community. In the outlined plane it is logical to take into account the regional aspect in the process of natural training of future bachelors of natural sciences as an agent of cultural development and a factor that determines the effective satisfaction of educational needs of students - representatives of different ethnic groups, a specialist capable of competently realizing the educational potential of the regional natural environment [1]. In view of this, the Ukrainian Danube as a center of transnational cultural ties is distinguished not only by a variety of natural resources, which fully applies to the Danube as one of the most important rivers in Europe, but also serves as a kind of ethno-educational environment to improve the natural training of future teachers. Thus, the consideration of general cultural competence of future bachelors of natural sciences in the context of the axiological approach to teaching the school integrated course «Natural Sciences», actualizes the request to improve the training system, given the updated strategies of the national education system, one of which is creation of the ethnocultural educational environment, which would facilitate the translation of universal and Ukrainian national values. 
The conducted analysis of scientific research shows that at the present stage the attention of both domestic and foreign scientists is increasingly focused on deepening scientific ideas about ways to improve the training of future teachers of natural sciences, including biology (N. Kalinichenko [2], N. Gritsay [3], G. Fahrutdinova [4], R. Schneider [5], and others). Instead, the ethnopedagogical segment of the local history material of the population of the Danube is not used in the process of professional development of future bachelors of natural sciences, where the Danube River acts as a kind of catalyst for intercultural interaction. After all, the change of pedagogical paradigm at the present stage necessitates the training of future teachers as carriers of social culture. The latter is interpreted by a number of scholars as a philosophy of life (V. Andruschenko [6], Berezyuk [7], V. Kremen [8] and others. Summarizing the views of scientists on the problem, we can argue that strengthening the axiological aspect of modern pedagogical education involves the formation of general cultural competence of future teachers in a specially organized subject training in the context of the manifestation of valuable human resources. Of particular importance is the outlined issue in connection with the concept of sustainable development of mankind, aimed at actualizing the value dimension of socio-cultural existence of human. In this aspect the work by V. Grinev [9], where the key is the idea of systemic application in natural education of the emotional and value component of ethnic traditions, is constructive.

The issue of ethnopedagogical training of future teachers and the formation of his/ her general cultural competence has been widely covered in the scientific research of foreign scientists (S. Baciu [10], O. Duhlicher [11], V. Goras-Postika [12]), who emphasized the importance of cultivating the ethnic culture of the individual. In particular, scholars considered ethnopedagogical knowledge as the basis of spiritual and moral development of teachers.

Thus, according to N. Silistraru [13], folklore as an ethnopedagogical value reflects the human psyche and is a form of social consciousness that generates norms of behavior in various life situations, supports the existence of traditions, influences the formation of personal beliefs. In addition, N. Silistraru, for example, interprets the ethnopedagogical education of future teachers as a kind of social education. The ethnopedagogical aspect of the professional training of the future teacher as the primary inclusion of the individual in the system of social relations that influence the formation of personal qualities of students was considered by T. Panco [14]. Thus, the analytical review of scientific works on the training of future teachers, suggests that the scientific interests of both domestic and foreign scholars are increasingly focused on the formation of general cultural dominance of pedagogical activities of future teachers as organizers of educational activities on the basis of polyethnicity. Thus, it is obvious that the problem of motivated and systematic use of a kind of resource-ethnopedagogical idea, in particular, dictated by such a factor as the Danube River, becomes especially relevant.

Given the above, the aim of the article is to intensify the ethnopedagogical component of training of future bachelors of natural sciences on the example of plant symbolism in the calendarritual traditions of the ethnic groups of the Danube interfluve.

\section{Materials and methods of research}

To achieve this goal, the work uses a set of methods of scientific knowledge, including logical generalization and systematic analysis of theoretical positions, specification of key concepts and practical experience in the context of research.

\section{Results and discussion}

Modern education is characterized by the strengthening of the axiological component in all its diversity, an indicator of which is the general cultural competence of the individual as key in the context of intercultural interaction. In this regard, in the context of profiling the high school of Ukraine, the core of professional training of future teachers is a cultural dominant, which determines the ability of the individual to navigate in a multicultural space, apply the achievements of national and world culture in the formation of universal values. It is worth emphasizing, that the modern updated strategy of natural education provides not only for students' mastering fundamental scientific knowledge, but also understanding the ethnocultural aspect of its content. 
It is indisputable, that the interest in the subject is formed under the direct personal and professional influence of the teacher, his/her ability to convey to students not only their own attitude to the content of education, but also to ensure the creative nature of teaching, particularly in ethnopedagogy. With this in mind, the subjectivity of the future natural science teacher as an integrative property of general cultural competence manifests itself in the ability to successfully interact in a multicultural environment. To this we add that the basis of professional competence of the future teacher is primarily the culture of the individual. According to N. Bibik, in the context of the new philosophy of education, it is the axiological approach that plays an important role in the development of Ukrainian society, through the formation of students' general cultural competencies [15, p.42].

Thus, in the context of our study, the ethnopedagogical concept of subject training of future bachelors of natural sciences is a necessary condition for professional education and serves as a strategy for the formation and development of general cultural competence of the subjects of the educational process. This highlights the problem of readiness of future bachelors of natural sciences to implement the emotional and value component of the content of the school course «Natural Sciences» by ensuring the integration of competency and ethnopedagogical approaches.

Thus, the outlined task forms the need for significant intensification of the process of formation of general cultural competence of future bachelors of natural sciences through directed interaction and cooperation of all participants of the educational process on the basis of ethnopedagogy. In addition, given the strengthening of integration processes in the European educational space, the phenomenon of general cultural competence is mostly seen as the ability of the individual to engage in interethnic interaction while preserving national identity, based on a combination of personal qualities, synthesized ethnographic knowledge, traditions, stereotypes [16, p. 13].

We find it expedient to state that the basis for the formation of general cultural competence of future bachelors of natural sciences in the process of practice-oriented training is natural literacy as a component of the general culture of the individual. Therefore, the ethnopedagogical component of the content of professionally oriented disciplines as a result of cognitive activity of students, serve as a conceptual basis for developing a professional position of the future teacher, which accumulates folk experience in various spheres of life.

It should be noted, that it is impossible to successfully educate a person without involving him/her in the original pedagogical culture of his/her people [17]. Thus, given today, the strategy of the national school is to involve young people in ethnic, national and world cultures, as part of the process of forming a willingness to live in a multinational environment.

In view of this, the idea of including ethnopedagogical component in the content of natural sciences is a necessary condition for professional development of future bachelors of natural sciences, which intensifies the process of gaining ethnopedagogical experience of interaction in the natural and social environment. In addition, ethnographic knowledge as a powerful resource for understanding the fundamental benefits of ethnopedagogy has a significant influence on the moral views, beliefs and professional identity of the future teacher.

Based on the above, we will consider some aspects of ethnopedagogical experience of natural training of students of Izmail State Humanitirian University in specialties 014.15 Secondary Education (Natural Sciences) and 014.05 Secondary Education (Biology and Fundamentals of Human Health) given the regional identity. We note that the multiculturalism of the Ukrainian Danube is actively studied by historians, ethnographers, philologists and teachers (E. Bazarova, I. Verkhovtseva, O. Lunyova, V. Kokosh, V. Teleutsya, A. Chirva, L. Tsyganenko, T. Shevchuk, P. Kiseolar) and for many years is considered an advantage of the region, which demonstrates a tolerant model of behavior of representatives of different ethnic groups.

Note that international rivers have always played an important role in the economic, political and social aspects of life in cross-border regions. It is natural, that the Danube, as the second longest in Europe, is also the main source of food for the Ukrainian Danube region, home to about half a million people, and a kind of symbol that governs most intercultural and cross-border relations. The self-consolidating role of the Danube in maintaining intercultural ties ensures the sustainability of ethnocultural traditions and the multicultural nature of the region. 
Given this, the involvement of cultural heritage of different ethnic groups in the region in the process of professional training of future bachelors of natural sciences will significantly increase the level of their general cultural competence and provide students with awareness of the cultural mission of the teacher.

Thus, in order to enrich the general cultural and subject competence of future bachelors of natural sciences, we actively implemented the idea of including the ethnopedagogical component of local lore material in the content of professionally-oriented disciplines, including botany and biogeography. It is this context of professional training of future teachers provides dialogue of cultures, preservation and creation of new cultural values and practical involvement of students in the acquisition of ethnopedagogical experience, by understanding the philosophical, moral and aesthetic aspects of the content of natural education.

The fundamental basis of ethnopedagogization of professional training of future bachelors in the natural sciences was the scientific position of O. Gurenko [18], according to which the cultural direction of educational content involves creative activities to promote the best examples of national culture and integration of the ethnic student community in a highly developed modern nation.

The structural component of any cultural heritage is ethnic symbols as an image or object that represents an abstract idea that affects the emotional and subconscious sphere of human. Note that symbolism in the structure of ethnocultural approach to teaching natural sciences has a great educational value and develops over time along with culture. Taking into account that symbolism in the structure of ethnocultural approach to the teaching of natural sciences has a great educational value and develops over time along with culture, we focused on finding a plant, whose symbolic expression would unite the various ethnic groups in the Danube interfluve.

Based on the results of scientific research by H. Dubyna [19], it should be emphasized, that a prominent place in the ethnopedagogy of Slavic peoples is occupied by their own names, mostly geographical content (names of settlements, rivers, seas). The researcher carefully analyzes the folklore material, in particular the natural content of ritual songs, in which she singles out the most common name - the Danube River, which was well known to the Slavs as a personified image of «ancestral land and prosperity». [20, p. 117]. In addition, the scientist emphasizes the ambiguity of the interpretation of the name of the reservoir by different ethnic groups in the areas adjacent to the Danube, where it performed a purely nominative function, more related to the characteristics of the area. Thus, most of the use of the epithet «fast» by ethnic groups living in the upper part of the Danube is associated with the peculiarities of the relief of the delineated area, in particular the mountainous part of the riverbed. It is known, that the river is characterized by a more natural designation as «quiet». In addition, various interpretations of the symbolism of the Danube are carefully detailed, in particular it is interpreted as a symbol of love, close separation or meeting, as well as death [19, p. 3-4].

At the same time, careful detailing of the semantic meaning of the river's own name was not the end purpose of our study. Seeing the general philosophical and cultural spectrum of ethnonatural knowledge, it was one about the Euroregion «Lower Danube» that affected solving specific tasks - finding in the Ukrainian-Romanian part of the Danube region the most powerful natural symbols that reflect the vitality and sustainable development of the nation.

In this perspective, among many similar symbols of the multicultural environment, the leading place in ethnographic activities is occupied by such a plant as grapes, the image of which filled the equipment of ethnographic corners, exhibitions, living rooms, creative workshops, although in different ethnic centers its meaning differs slightly. In order to understand the symbolism of the outlined plant, which is part of the age-old foundations of the peoples of the Danube, it is necessary to involve students in the process of ethnic self-identification by studying and comparing the spiritual and moral principles of different cultures.

To this we add that the uniqueness of the cross-border region «Lower Danube» is that each represented unique group living in this area is also a carrier of regional cultural component, which affects the ethnic identity of diasporas and determines the existence of such a phenomenon as transculturalism. Thus, it is about the theoretical and practical significance of intercultural interaction of national and cultural associations, which provides support for their sustainability 
and development. Thus, the ethnocultural traditions of the region are in close connection with other types of culture and part of a single process of multicultural activity, acting as a holistic new formation of the socio-spiritual world of the individual.

According to I. Balashenko, ethnoculture as a systemic phenomenon of human relations, permeates the main varieties of general culture of the individual and performs an integrative function, as it allows to preserve in people's minds the uniqueness and originality of folk culture of each ethnic group and determines the internal imperative of ethnic communities' life activity [21, p. 92]. Finally, ethnocultural knowledge is a kind of process of accumulation and transfer of social experience of development of peoples in order to consolidate the most valuable and advanced in it [22].

Given the fact that the Ukrainian, Bulgarian and Romanian ethnic groups are the most numerous in the Danube interfluve, the original symbolism of grapes in ethnographic traditions, customs and rites, which in one way or another perform a unifying function between the past and future of the people, was taken into account. Thus, one of the oldest symbols of fertility, prosperity and wealth of these ethnic cultures is grapes.

Common in the idea of nationalities is the interpretation that the vineyard - humanity, a separate vine - the country, a bunch of grapes - the family, and the berry - a separate person. Therefore, for a long time there was a respectful attitude to grapes as a symbol of revival, and the characteristic ethnic motif of ornamental compositions of interior decoration is the image of a grape vine, which in folk culture symbolizes the strength of family life, fertility, well-being, wealth and diligence. And to this day there are traditions of weaving wreaths of vines, in particular in the traditional rituals of the Bulgarians. In particular, an example of intercultural interaction is the ancient Balkan holiday «Trifon Zarezan», which is celebrated not only by winegrowers of the Danube region, but also gardeners and owners of wine production. In addition, the vine is still present as a symbol of prosperity and well-being. Although in the traditions of the Ukrainian Danube region, the bunch of grapes symbolizes inner spirituality, the sacredness of which lies in the revival of life.

Based on the understanding that various components of ethnopedagogy involve young people in humane relations, the research component of the study of the fundamental course «Fundamentals of Botany» included the study of ethnographic sources, studying the originality of the natural context of the most common traditions and rites, which occupy a leading place in the ethnographic activities of the population of the Danube. It should be noted, that the involvement of future bachelors of natural sciences in humane relations contributes not only to the formation of subject competence as a defining professional activity, but also to the awakening of young people's national consciousness, which is reflected in moral principles and humanistic ideals.

Organizing student youth to master the ethno-natural component of the cultural heritage of the multicultural region, the most common forms of work were: excursions to local history museums, ethnic courtyards, art and creative workshops, cultural centers in which future professionals participated in the preparation of thematic days, theater holidays, ceremonies, practical activities on the study of ethnic identity of communities.

Thus, it is interesting to note that among the Bulgarian household traditions, the habit of identifying a person by the nature of his/her activity is still preserved, as a rule in ethnic settlements. According to the results of R. Yamleev's scientific research on the essence of the semantic meaning of ethnic names, including the Bulgarian ethnos, for example, the name Gostun is nothing but distorted by dialectal features and written in Cyrillic Sumerian word «grapes», which was inherited based on the ancestral transmission principle of viticulture knowledge [23]. In turn, Romanian speakers interpret the symbol of grapes in their own way. In particular, following the traditional original style of the Moldavian settlements of the Danube, grapes as a plant have historically been a means of payment and a trophy in battles, which contributed to its nationalization as a product. In addition, according to unofficial data, the southern part of the Republic of Moldova is considered the place of origin of the vine, and its geographical image is identified with the bunch. Viticulture has become so widespread in Moldovan culture that the position of cupbearer has historically been established, whose responsibilities include overseeing vineyards and controlling the quality of 
wine. Even in the territory of the Ukrainian Danube region, uniquely decorated wine estates have been preserved, which preserve their age-old traditions.

In the students' personal perception of the internal component of general cultural values, those that actualize the national spirit, provide awareness of the moral and ethical essence of the national idea, have a specific weight. Taking into account the conclusions made by O. Nadybska [24] that the national consciousness has cognitive and emotional components, future bachelors of natural sciences studied the symbol of grapes, which is represented in the motifs of embroidery and the peculiarities of its biogeographical distribution within the Euroregion «Lower Danube».

Scientific research has shown that the choice of pattern for a shirt was determined primarily by those, for whom it was embroidered. In particular, for boys, combinations of geometric shapes were usually chosen, mostly crosses, and girls were dominated by plant motifs, mostly flowers. The mothers decorated the edges of the shirt with a vine with intertwined twigs of leaves and grape berries, which was a symbol of female fertility. In addition, given the fact that the existence of multifaceted crops in one area is not possible without the interpenetration of its individual components, there are patterns of grapes on male child's shirts of purely blue color. It was believed that such an ornament serves as a kind of protection for babies.

In contrast, in the Ukrainian settlements of the Danube region, bunches of grapes, embroidered on towels, represent the joy of creating a family. Ornament of garden-grapes on the attributes of national dress symbolizes the field of life, where a man plays the role of a sower, and a woman is a caretaker, who grows and nurtures a family tree.

Visiting the creative workshops of local artists (O. Kara, I. Shishman, V. Dudnik, I. Pastir), as well as the Izmail Museum of History and Local Lore of the Danube, our observations allow us to state that most of the paintings, the authors of which are carriers of different cultures, contain such symbols as bread and grapes, which is identified with the result of hard work of the farmer as a traditional activity of the inhabitants of the Euroregion. In addition, the grapes on the canvases of Bulgarian artists are marked as a symbol of joy of life and youth. At the same time, the specificity of the designation of exquisite curves of grape tendrils and leaves on the paintings of Ukrainian artists is a symbol of the flowering of the spirituality of the people.

Thus, the decisive role in shaping the national consciousness of multicultural society is played by the ethnoconsciousness of future teachers, which is based on ethnocultural values, which include language, stereotypes, historical experience, religion, folk art, traditional everyday life.

One of the consolidating factors of intercultural interaction of ethnic groups in the lower part of the Danube is religion and the symbolism of its attributes. Thus, in the Ukrainian part of the Danube, Christianity has become the most widespread, according to which the image of the vine is characteristic of all ethnic groups and is the brightest element of religious paraphernalia, which has its own secret meaning. In particular, the vine with bunches as a symbol of salvation and new life is widely represented in the form of the paintings on the inner walls of temples, as well as an element of decor on the iconostasis. In addition, the grape theme adorns the upper liturgical clothing of the clergy as a symbolism of the decoration of human souls. It is interesting that the vine is interpreted in religious texts and images as a tree of life, and the bunch is a symbol of the results of human life. Some Christian traditions, associated with grapes, are still present in the rituals of Bulgarians, Moldavians, Ukrainians and other ethnic groups in the Danube region In particular, dried grapes are used as a symbol of death in traditional funeral dishes.

Thus, national images, stereotypes of behavior, emotional coloring of traditions, reflection of ethnic mentality are the defining feature and indisputable proof of interethnic integrity of both the Ukrainian Danube and Ukraine as a whole.

It should be noted, that folk art creates a powerful basis for the development of not only national, but also spiritual culture. In this regard, future bachelors of natural sciences were involved in this type of art as Easter painting, which is characteristic of the purely Ukrainian people. The combination of knowledge of the historical past, its cultural traditions, with the content of the integrated school course «Natural Sciences» allows future teachers to expand its subject matter, to involve elements of natural images through in the process of teaching students the use of folk style. Thus, students' study of regional symbols of Easter painting revealed that the most characteristic 
for the South of Ukraine is the blue color scheme, as a symbol of reservoirs - life-giving sources of the region.

Easter eggs on the Danube are distinguished by images, including clover flowers, lilies of the valley, tulips, oak leaves and more. This is mostly due to the floral originality of the region. Among the plant ornamental motifs on Easter eggs were found images of grapes - a symbol of wisdom and immortality. Thus, the activation of the ethnopedagogical aspect of the culturological component of natural training of future teachers contributes to their acquisition of ethnopedagogical teaching experience.

\section{Conclusions}

Intercultural competence is an integral part of the professional training of future teachers of the New Ukrainian School. In particular, the involvement of future bachelors of natural sciences in national and universal values contributes to the acquisition of practical experience of interethnic dialogue in the process of forming natural science ideas of students. In addition, the effectiveness of educating the culture of interethnic relations of student youth largely depends on the level of ethnocultural preparedness of the teacher, his/her level of general cultural competence. Therefore, the readiness of future bachelors of natural sciences for subject activities in the multicultural space of the educational institution is a kind of condition of pedagogical support for the development of ethnocultural identity of the student and the implementation of a new strategy of natural education integration of humanities and science.

In the personal dimension the formation of general cultural competence of the future teacher of natural sciences identifies him/her as a carrier of national ideas, norms and traditions, affirming national and ethnic personal intrinsic value of the teacher of the new generation.

\section{References}

[1] Gramatyk N. V. (2017). Rehionalnyi vektor pryrodnychoi pidhotovky maibutnikh uchyteliv pochatkovykh klasiv u parametrakh yevropeiskykh standartiv vyshchoi osvity. Teoretyko-metodychni problemy vykhovannia ditei ta uchnivskoi molodi: zb. nauk. prats - Tematychnyi vypusk «Vyshcha osvita Ukrainy u konteksti intehratsii do yevropeiskoho osvitnoho prostoru», 2 (21), 8-18.

[2] Kalinichenko, N. (2017). Actual directions for preparing the future teachers of biology. The pedagogical process: Theory and Practice, 4, 26-32.

[3] Hrytsai, N. B. (2016). Systema metodychnoi pidhotovky maibutnikh uchyteliv biolohii v pedahohichnykh universytetakh: dys. doktora ped. nauk: Systema metodychnoi pidhotovky maibutnikh uchyteliv biolohii v pedahohichnykh universytetakh. V. H. Korolenka. Poltava.

[4] Fahrutdinova, G. Zh. (2016). Ethno-Pedagogical Factor of Polycultural Training. International Journal of Environmental \& Science Education, 11 (6), 1185-1193. Available at: https://files.eric.ed.gov/fulltext/EJ1114272.pdf

[5] Schneider, R. M., Plasman, K. (2011). Science Teacher Learning Progressions. Review of Educational Research, 81 (4), $530-$ 565. doi: http://doi.org/10.3102/0034654311423382

[6] Andrushchenko, V. (2016). Vchytel KhKhI stolittia: nova stratehiia Natsionalnoho pedahohichnoho universytetu imeni M. P. Drahomanova. Vyshcha osvita Ukrainy, 4, 5-14.

[7] Bereziuk, O. S.; Dubaseniuk, O. A. (Ed.) (2015). Systemnyi pidkhid do formuvannia polikulturnoi kompetentnosti maibutnikh fakhivtsiv v suchasnomu osvitnomu prostori. Profesiina pedahohichna osvita: systemni doslidzhennia: monohrafiia. Zhytomyr: Vyd-vo ZhDU im. I. Franka, 193-209.

[8] Kremen, V., Ilin, V. (2014). Kreatyv filosofii osvity v synerhii suchasnoho znannia. Filosofiia osvity : khrestomatiia navch. posib. dlia stud. VNZ. - Kyiv: Kyiv. un-t im. B. Hrinchenka, 469-473.

[9] Grinyova, V. M., Novikov, O. V., Yuryeva, K. A. (2017). professional training stages of future teachers and educators on the basis of comparative ethnography. Zasobi navčal'noj ta naukovo-doslìdnoï roboti, 48, 47-65. Available at: https://core.ac.uk/ download/pdf/229048093.pdf

[10] Baciu, S. (2007). Perspective curriculare etnopedagogice încăutareavaloriloruitate, «Univers pedagogic», Chişinău.

[11] Duhlicher, O. Competenţa De Educaţie Interculturală, dimensiune a comportamentului professionalalprofesorului. Available at: https://ibn.idsi.md/sites/default/files/imag_file/Competenta\%20de\%20educatie\%20interculturala.pdf

[12] Goras-Postika, V. (2015). Competenţa interculturală Auxiliar didactic. Centrul Educațional PRO DIDACTICA, Consiliul Naționalal Tineretuluidin Moldova. Tipar: Casa Editorial-Poligraică «BonsOices». 
[13] Silistraru, N. (2013). Valori etnopedagogice ca modele ale educaţiei culturii populare. UniversitateadeStatdinTiraspol (cuse diullaChişinău). Available at: https://ibn.idsi.md/sites/default/files/imag_file/170_177_Valori\%20etnopedagogice\%20ca\%20 modele\%20ale\%20educatiei\%20culturii\%20populare.pdf

[14] Panco, T. (2015). Formirovanie etnopedagogicheskoj kompetentnosti budushchih uchitelej v processe professional'noj podgotovki. Tradiţii şi valoriîn formareaprofesională a cadrelordidactice în învăţămîntulpreşcolar şi primar: Materialeleconf. şt. intern. consacratăaniversării a 55-a delafondareaFac. deŞtiinţealeEducaţiei, Psihologie şi Arte, Bălţi. Available at: http:// dspace.usarb.md:8080/jspui/bitstream/123456789/3234/1/culegere_conf_jubiliara_FSEPA.pdf

[15] Bibik, N. M.; Ovcharuk, O. V. (Ed.) (2004). Kompetentnisnyi pidkhid: refleksyvnyi analiz zastosuvannia. Kompetentnisnyi pidkhid u suchasnii osviti: svitovyi dosvid ta ukrainski perspektyvy. Kyiv: «K.I.S.», 47-50.

[16] Bereziuk, O. S.; Bereziuk, O. S., Vlasenko, O. M. (Eds.) (2013). Formuvannia polikulturnoi kompetentnosti maibutnikh fakhivtsiv v suchasnomu osvitnomu prostori. Formuvannia zahalnokulturnoi kompetentsii maibutnikh fakhivtsiv: zbirnyk naukovykh prats. Zhytomyr: Vyd-vo ZhDU im. I. Franka, 10-19.

[17] Mashkina, C. V., Usatenko, T. P., Khomych, L. O., Shakhrai, T. O. (2016). Teoretychni zasady kulturolohichnoho pidkhodu u pidhotovtsi pedahoha do vykhovnoi diialnosti. Monohrafiia. IPOOD NAPN Ukrainy, 168.

[18] Hurenko, O. I. (2008). Etnokulturna kompetentnist ta yii formuvannia u studentiv pedahohichnoho universytetu: tekhnolohichnyi aspekt: Monohrafiia. Donetsk: TOV «Iuho-Vostok, LTD», 240.

[19] Dubyna, N. M.; Karpenko, Yu. O. (Ed.) (2000). Funktsii toponimiv u vesniankakh / N. M. Dubyna // Zapysky z onomastyky: zb. nauk. pr. Odesa: Astroprynt, 4, 47-54.

[20] Karpenko, Yu. O. (1999). Tihij Dunaj. Vostochno-ukrainskij lingvisticheskij sbornik. Doneck, 5, 3-9.

[21] Balashenko, I. V. (2006). Etnokultura v kontekste razvitiya yazykovogo prostranstva. Kultura narodovPrichernomorya, 89, 95-99. Available at: http://dspace.nbuv.gov.ua/bitstream/handle/123456789/36656/27Balashenko.pdf?sequence=1

[22] Cheban, O. M. (2001). Etnokulturne u svidomosti liudei polietnichnoho sotsiumu (na materiali Prydunavia). Odesa: PDPU im. K.D. Ushynskoho, 20.

[23] Yamleev, R. A. (2010). Vinograd v zhiznityurks'kihnarodov. Molodoj uchenyj, 12 (2), 39-47.

[24] Nadybska, O. Ia. (2002). Natsionalne u samosvidomosti polietnichnoho sotsiumu. Odesa: PDPU im. K.D.Ushynskoho, 19.

[25] Jernigan, V. B., Hearod, J. B., Tran, K., Norris, K. C., Buchwald, D. (2016). An Examination of Cultural Competence Training in US Medical Education Guided by the Tool for Assessing Cultural Competence Training. J Health Dispar Res Pract., 9 (3), 150-167. Available at: https://www.ncbi.nlm.nih.gov/pmc/articles/PMC5091804/

How to cite. Gramatyk, N. (2021). The danube river as an activation factor of the ethnopedagogical component of general cultural competence of bachelors in natural sciences. EUREKA: Social and Humanities, 2, 44-51. doi: http://doi.org/10.21303/25045571.2021.001719 